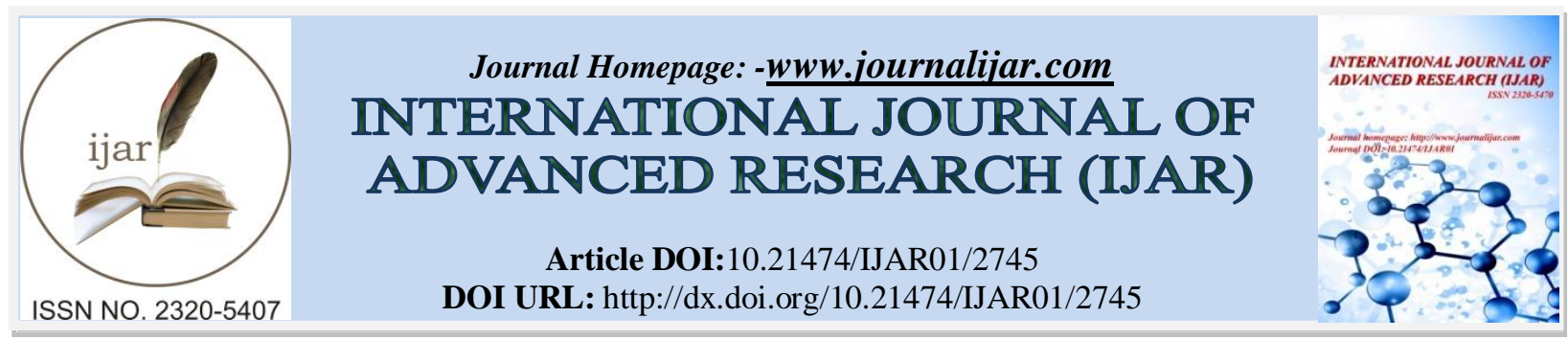

RESEARCH ARTICLE

\title{
EFFECT OF PLANT GROWTH REGULATORS ON IMMOBILIZED CELL CULTURE OF ADHATODA VASICA NEES.
}

\author{
Chauhan Pradeep*1, Panigrahi Mahendra Kumar ${ }^{2}$, Behera Jayanti Prava ${ }^{3}$. \\ 1. Institute of Professional Studies-College of Pharmacy, Gwalior, M.P. 474001. \\ 2. Hi-Tech College of Pharmacy, Hi-Tech Medical College and Hospital Campus, Bhubneswar, Odisha, 751025. \\ 3. PG Department of Pharmacology, M.K.C.G. Medical College, Brahmapur, GM, Odisha.
}

\section{Manuscript Info}

(..........................

Manuscript History

Received: 15 November 2016

Final Accepted: 17 December 2016

Published: January 2017

Key words:-

A. vasica, Immobilized cell, calcium

alginate, cell growth, vasicine.

\section{Abstract}

Immobilization have been suggested as a strategy to improve the overall productivity in plant tissue culture. Two auxin and one cytokine used to manipulate the media and the effect was studies in terms of cell growth. Secondary metabolite production was analyzed by HPLC.

The calcium alginate concentration was optimized on the basis of cell viability and cell number increase was observed in immobilized condition.

\section{Introduction:-}

Immobilized system facilitates cell viability over an extended time for secondary metabolite production. Immobilization enables reutilization of entrapped biomass, and this technique is especially suitable for slow growing plant cells. Immobilized plant cells have been employed to perform biotransformation and reported to have higher production from suspension culture cells. Enclosure in a support material exerts certain stress on plant cells leading to restricted growth, the condition normally considered as prerequisite for higher secondary metabolite production (Brodelius, 1979).

Immobilization separates cells from medium and the desired product is extracellular, simplifying down-stream processing.Manipulation of the auxin to cytokinin ratio in the medium can lead to the development of shoots, roots, or somatic embryos from which whole plants can subsequently be produced (Haigh,1989).

Immobilized plant cells have been employed to perform biotransformations and reported to have higher production rates than freely suspended cells. For example, immobilized Capsicum cultures treated with precursors accumulated more quantities of biotrasnformed compounds than freely suspended cultures (Johnson et al., 1996; Rao and Ravishankar, 2000). Immobilization techniques were initially developed to immobilize enzymes for applications in the industrial production of sugars, amino acids and pharmaceutical products (Vasilev, 2014). In an immobilized system growth and production phases can be decoupled and controlled by chemical and physical stress conditions. This allows cells to be retained in the bioreactor for extended periods, with alternating rejuvenation /growth and secondary metabolite production cycles (Williams and Mavituna, 1992). 
AdhatodavasicaNees (Vasaka) is used in various chest infections and has reputation as an expectorant in the indegenious system of medicine. The leaves, roots and flowers are extensively used for various respiratory disorders like cough, asthama, bronchitis etc. Adhatodavasica has been used for centuries in India as an insecticide. Its leaves have been shown to control insect pests in oil seeds, in both laboratory and warehouse conditions (Srivastava, 1965). It provides relieves in muscular spasms, cramps or convulsions. Vasicine (peganine) is a quinazoline alkaloid (Atal, 1980). It is the active compound of A. Vasica.

\section{Material and method:- \\ Immobilization in calcium alginate-}

$1 \mathrm{ml}$. of cell suspension, corresponding to $1 \mathrm{gm}$ of fresh weight was added to $10 \mathrm{ml}$. of $2 \%$ sodium alginate (HImedia) and mix well to achieve the uniform distribution of cells throughout the sodium alginate solution and left for sometime to remove bubbles. This mixture was then added drop wise into $3 \mathrm{mM}$ calcium chloride solution through sterilized syringe under aseptic condition in Laminar airflow bench. This leads to form circular beads having diameter of $2.5-3.0 \mathrm{~mm}$. Formed beads are then left in $\mathrm{Cacl}_{2}$ solution for 30 minits for stabilization. The beads were then washed with sterilized water to remove the traces of $\mathrm{Cacl}_{2}$. Washed beads were then dispersed in $50 \mathrm{ml}$. production media in Erlenmeyer flasks in shaker cum incubator.

Optimization of calcium alginate concentration by cell viability study:-

Immobilized cells are subjected to check the viability in calcium alginate entrapped condition. For cell viability study 5 beads are placed in $5 \mathrm{ml}$. of potassium phosphate buffer ( $\mathrm{pH}$ 6.5) to release the cells from calcium alginate. After complete dissolution of beads the obtained suspension was centrifuge at $2000 \mathrm{rpm}$ for $2 \mathrm{~min}$ and $1 \mathrm{ml}$. of 23.9 mM TTC (Tri phenyl tertazoliumcloride) was added in separated cells in micro centrifuge tubes.

Cell Number increase study in calcium alginate immobilized cells:-

Cell number was estimated by dissolving the randomly selected 10 beads in $10 \mathrm{ml}$. of potassium phosphate buffer ( $\mathrm{pH}$ 6.5). After ensuring the complete dissolution of beads, the cells were counted under the microscope with cytometer.

\section{HPLC Quantitative estimation of Vasicine:-}

TheQuantitative estimation of Vasicine was analyzed qualitatively was done by High Performance Liquid Chromatography (HPLC) method (Indian Herbal Pharmacopoeia, 1998). The different dilutions dilutions of known concentration of vasicine (Provided by Laila Impex, Vijaywada) was prepared by dissolving them in methanol to get the concentration range between $10-60 \mu \mathrm{g} / \mathrm{ml}$.

\section{Sample preparation:-}

For quantitative estimation of vasicine in immobilized cell culture, $25 \mathrm{ml}$ production media was taken out from four flasks and pooled together to make it $100 \mathrm{ml}$. Which is then subjected for acid-alkali method ${ }^{7}$ to extract alkaloidal fraction. At the end of process a semi solid mass was remains, was further dissolved in methanol and use for HPLC estimation.

\section{HPLC Standard curve for Vasicine:-}

Instrument: Shimedzu, Mobile phase: Methanol: water (2:3), Flow rate: $0.7 \mathrm{ml} / \mathrm{min}$. Column: Resolve C18 Spherical $5 \mu$ (3.9 mm X 15 cm), Detector: SPD-M10 Avp. Wavelength: $298 \mathrm{~nm}$, Retention time: $3.8 \mathrm{~min}$.

\section{Results and discussion:-}

From the above results it was observed that the immobilization of A. vasica cells in calcium alginate gel is showing promising results. $2 \%$ calcium alginate was found optimum for immobilization as it maintains higher degree of cell viability. Immobilization restricted cell number increment, which stimulates secondary metabolite productions. MS media was found suitable for more vasicine production, maybe due to higher concentration of ions and nutrient supplements, which provide necessary material for de-novo synthesis of vasicine. The above study showed that MS media supplemented with 2,4-D (2 ppm), Kinetin $(0.5 \mathrm{ppm})$ and + IAA $(0.5 \mathrm{ppm})$ is suitable for more vasicine production. 
Table 1. Percentage cell viability in different alginate gel concentration.

\begin{tabular}{|c|c|c|c|}
\hline \multirow{2}{*}{ Time in Days } & \multicolumn{2}{|c|}{ \% viability in different alginate gel concentration } \\
\cline { 2 - 4 } & $1 \%$ & $2 \%$ & $3 \%$ \\
\hline 0 & 73 & 76 & 71 \\
\hline 7 & 69 & 71 & 64 \\
\hline 14 & Beads Dissolved & 68 & 61 \\
\hline 21 & Beads Dissolved & 65 & 55 \\
\hline
\end{tabular}

Table 2. Cell number study in MS and $B_{5}$ media immobilized in $2 \%$ calcium alginate.

\begin{tabular}{|c|c|c|c|c|c|c|}
\hline \multirow{2}{*}{$\begin{array}{l}\mathbf{D} \\
\mathbf{A} \\
\mathbf{Y} \\
\mathbf{S}\end{array}$} & \multicolumn{3}{|c|}{$\begin{array}{c}\text { Cell number X } 10^{5} / \mathrm{mm}^{3} \text { in MS Media } \\
\text { Supplemented with }\end{array}$} & \multicolumn{3}{|c|}{$\begin{array}{c}\text { Cell number X } 10^{5} / \mathrm{mm}^{3} \text { in } B_{5} \text { Media } \\
\text { supplemented with }\left(\text { cell number } X 10^{5}\right)\end{array}$} \\
\hline & $\begin{array}{l}\text { 2,4-D } \\
(2.0 \text { ppm })+ \\
\text { Kinetin } \\
(1.0 \text { ppm })+ \\
\text { IAA } \\
(0.5 \text { ppm })\end{array}$ & $\begin{array}{l}\text { 2,4-D } \\
(2 \mathrm{ppm})+ \\
\text { Kinetin } \\
(0.5 \mathrm{ppm})+ \\
\text { IAA } \\
(0.5 \mathrm{ppm})\end{array}$ & $\begin{array}{l}\text { 2,4-D } \\
(1.5 \text { ppm })+ \\
\text { Kinetin } \\
(1.0 \text { ppm })+\text { IAA } \\
(1.0 \text { ppm })\end{array}$ & $\begin{array}{l}\text { 2,4-D } \\
(2 \mathrm{ppm})+ \\
\text { Kinetin } \\
(1.0 \mathrm{ppm})+ \\
\text { IAA } \\
(0.5 \text { ppm })\end{array}$ & $\begin{array}{l}\text { 2,4-D } \\
(2 \mathrm{ppm}) \text { Kinetin } \\
(0.5 \mathrm{ppm})+ \\
\text { IAA } \\
(0.5 \mathrm{ppm})\end{array}$ & $\begin{array}{l}\text { 2,4-D } \\
(1.5 \text { ppm) + } \\
\text { Kinetin } \\
\text { 1.0 ppm) + IAA } \\
(1.0 \text { ppm) }\end{array}$ \\
\hline 0 & 3.6 & 3.62 & 3.54 & 3.3 & 3.61 & 3.42 \\
\hline 7 & 3.67 & 3.75 & 3.6 & 3.41 & 3.75 & 3.42 \\
\hline 14 & 3.84 & 4.14 & 3.74 & 3.48 & 3.76 & 3.46 \\
\hline 21 & 3.86 & 4.16 & 3.77 & 3.52 & 3.80 & 3.50 \\
\hline
\end{tabular}

Value represent the mean $\pm S E(n=3)$

Table 3. Vasicine content in immobilized cell culture.

\begin{tabular}{|c|c|c|c|c|c|c|}
\hline \multirow{3}{*}{$\begin{array}{l}\text { Time } \\
\text { in days }\end{array}$} & \multicolumn{6}{|c|}{ Vasicine content $(\mu \mathrm{g} / \mathrm{ml} / \mathrm{gm}$ fresh weight) of $A . v a s i c a$ cells immobilized in calcium alginate } \\
\hline & \multicolumn{3}{|c|}{ MS medium supplemented with } & \multicolumn{3}{|c|}{$\mathbf{B}_{5}$ medium supplemented with } \\
\hline & $\begin{array}{l}\text { 2,4-D } \\
(2.0 \text { ppm })+ \\
\text { Kinetin } \\
(1.0 \text { ppm })+ \\
\text { IAA } \\
(0.5 \text { ppm })\end{array}$ & $\begin{array}{l}\text { 2,4-D } \\
(2 \mathrm{ppm})+ \\
\text { Kinetin } \\
(0.5 \text { ppm })+ \\
\text { IAA } \\
(0.5 \text { ppm })\end{array}$ & $\begin{array}{l}\text { 2,4-D } \\
(1.5 \text { ppm })+ \\
\text { Kinetin } \\
(1.0 \text { ppm })+ \\
\text { IAA } \\
(1.0 \text { ppm })\end{array}$ & $\begin{array}{l}\text { 2,4-D } \\
(2 \mathrm{ppm})+ \\
\text { Kinetin } \\
(1.0 \mathrm{ppm})+ \\
\text { IAA } \\
(0.5 \mathrm{ppm})\end{array}$ & $\begin{array}{l}\text { 2,4-D } \\
(2 \mathrm{ppm}) \\
\text { Kinetin } \\
(0.5 \text { ppm) + } \\
\text { IAA } \\
(0.5 \text { ppm })\end{array}$ & \begin{tabular}{|l|} 
2,4-D \\
$(1.5$ ppm $)+$ \\
Kinetin \\
1.0 ppm $)+$ IAA \\
$(1.0$ ppm $)$
\end{tabular} \\
\hline 01 & $0.17 \pm 0.03$ & $0.30 \pm 0.05$ & $0.20 \pm 0.05$ & $0.29 \pm 0.05$ & $0.31 \pm 0.09$ & $0.19 \pm 0.04$ \\
\hline 07 & $0.48 \pm 0.03$ & $0.92 \pm 0.07$ & $0.61 \pm 0.07$ & $0.49 \pm 0.07$ & $0.90 \pm 0.07$ & $0.58 \pm 0.07$ \\
\hline 14 & $1.59 \pm 0.14$ & $2.51 \pm 0.21$ & $2.1 \pm 0.07$ & $1.98 \pm 0.04$ & $1.87 \pm 0.17$ & $1.75 \pm 0.04$ \\
\hline 21 & $1.73 \pm 0.09$ & $2.55 \pm 0.14$ & $2.20 \pm 0.09$ & $2.26 \pm 0.12$ & $2.50 \pm 0.12$ & $2.49 \pm 0.17$ \\
\hline
\end{tabular}

Value represent the mean \pm SE $(n=3)$

\section{References:-}

1. Brodelius, P.,Deus, B., Mosbach, K., and Zenk, M. H. (1979): Immobilized plant cells for the production and transformation of natural products. FEBS Letters, 103: 93 - 97

2. Haigh, J.R., Linden, J.C. (1989): Phenolicsproductino by encapsulated Nicotianatabacum cells. Plant Cell Reports, 8: 475 478.

3. Indian Herbal Pharmacopoeia, Joint publication of CSIR and Regional Research Laboratory, Jammu (India), 1992; 1-13.

4. Johnson, T. S., Ravishankar, G. A. and Venkataraman, L. V. (1996), Biotransformation of ferulic acid and vanyllylamine to capsicin and vanillin in immobilized cell culters of Capsicum frutescens, Plant Cell, Tissue and organ Culture, $44: 117$ 121.

5. Atal, C.K. (1980): Chemistry and Pharmacology of vasicine: A new oxytocin and abortifacient. Indian Drugs, 15: 15-18.

6. Rao, S. R. and Ravishankar, G. A., (2000): Biotransformation of protocatechuic aldehyde and caffeic acid to vanillin and capsaicin in freely suspended and immobilized cell cultures of Capsicum frutescens. Journal of Biotechnology, 76 : 137 146.

7. Vasilev, N., Schmitz, C., Grömping, U., Fischer, R., Schillberg, S (2014): Assessment of Cultivation Factors that Affect Biomass and Geraniol Production in Transgenic Tobacco Cell Suspension Cultures. PLOS One, 9 (8): 1-7.

8. Williams, P. D. and Mavituna, F., (1992). Immobilized Plant Cells, in Plant Biotechnology: Comprehensive Biotechnology, Second Supplement, Fowler, M. W., Warren, G. S. and Moo-Young, M., Pergamon Press, Oxford.

9. Srivastava AS, Saxena HP, Singh DR. Adhatodavasica, a promising insecticide against pests of storage. Lab Dev 1965; 3(2):138 